\title{
Synergistic activity between Triphala and selected antibiotics against drug resistant clinical isolates
}

\author{
Amirthasingam Manoraj ${ }^{1}$, Vasanthi Thevanesam², B. M. R. Bandara ${ }^{3}$, Asela Ekanayake ${ }^{2}$ and \\ Veranja Liyanapathirana ${ }^{2^{*}}$ (D)
}

\begin{abstract}
Background: Triphala is an indigenous medical product used for a variety of diseases. This study was conducted to determine the effect of Triphala on antibiotic properties of gentamicin and oxacillin against multi-drug resistant organisms.

Methods: The checkerboard method was used to determine the synergy of Triphala with gentamicin and oxacillin against multi-drug resistant (MDR) Gram negative bacilli and methicillin-resistant Staphylococcus aureus (MRSA) using 2,3,5-triphenyltetrazolium chloride (TTC) assay. Fractional inhibitory concentration (FIC) index was calculated.

Results: When tested alone, the minimum inhibitory concentration (MIC) values of gentamicin for Gram negative isolates ranged from 8 to $>64 \mathrm{\mu g} / \mathrm{ml}$. The MIC values of gentamicin for the Gram negative isolates ranged from 1 to $32 \mathrm{\mu g} / \mathrm{ml}$ when tested with Triphala. The FIC index was $<1$ indicating a synergistic interaction in 10 of the 11 isolates and it was 1 indicating an additive effect in one isolate.

The MIC values of oxacillin for MRSA isolates ranged from 4 to $>16 \mu \mathrm{g} / \mathrm{ml}$ with all MICs being equal to or higher than the resistance cut-off level. The MIC level with the addition of Triphala ranged from 0.25 to $4 \mu \mathrm{g} / \mathrm{ml}$. FIC index was $<1$ for all tested isolates indicating a synergistic interaction.
\end{abstract}

Conclusions: Triphala has synergistic activity with gentamicin against the selected MDR Gram negative bacilli and with oxacillin against MRSA isolates warranting further studies on the possibility of clinical use.

Keywords: Triphala, Synergy, Gentamicin, Oxacillin, MDR gram negatives, MRSA

\section{Background}

Triphala is an indigenous medicinal product used in diseases in nose and skin wounds, tumours, cough and upper respiratory diseases, peptic ulcer, mouth ulcers, anemia, abdominal pain, obesity, liver diseases and toxic conditions [1-3]. It is composed of dried pericarp of the fruits of three plants, Terminalia chebula Retz. (Combretaceae), Terminalia bellirica (Gaertn.) Roxb. (Combretaceae) and Emblica officinalis L. (Euphorbiaceae) mixed in equal proportions (1:1:1) [1-4].

\footnotetext{
* Correspondence: veranjacl@yahoo.com; veranjacl@pdn.ac.lk

${ }^{2}$ Department of Microbiology, Faculty of Medicine, University of Peradeniya

Peradeniya, Sri Lanka

Full list of author information is available at the end of the article
}

The biological activity of Triphala has been studied in some detail, including in animal experiments. Triphala is known to have antimicrobial activity, anti-viral activity, anti-oxidant activity including the ability to scavenge free radicals, anti-inflammatory activity, anti-pyretic activity, wound healing properties, anti-mutagenic and anti-carcinogenic activity as well as hypoglycaemic effects [4-6]. Extracts of Triphala and its individual plants have demonstrated varying degree of activity against a range of Gram negative and Gram positive bacteria [7-10].

Furthermore, Triphala has also shown antibacterial activity against Enterococcus faecalis in biofilms formed on dental substrates [11]. A mouthwash prepared from Triphala has been effective in reducing dental plaque formation [12]

(c) The Author(s). 2019 Open Access This article is distributed under the terms of the Creative Commons Attribution 4.0 International License (http://creativecommons.org/licenses/by/4.0/), which permits unrestricted use, distribution, and reproduction in any medium, provided you give appropriate credit to the original author(s) and the source, provide a link to the Creative Commons license, and indicate if changes were made. The Creative Commons Public Domain Dedication waiver (http://creativecommons.org/publicdomain/zero/1.0/) applies to the data made available in this article, unless otherwise stated. 
Triphala has been incorporated in collagen sponges to reduce wound infection and facilitate healing [13].

Antimicrobial resistance (AMR) is a major issue faced by health care professionals globally. In addition to the identification of novel antibiotics, enhancing the activity of existing antibiotics by combining with novel compounds can also be considered as a strategy to overcome the problem of AMR.

Gentamicin is an aminoglycoside with activity against both Gram negative and positive organisms. Gentamicin is used routinely in combination with other classes of antibiotics in the treatment of different types of bacterial infections. Oxacillin is an indicator drug used to assess sensitivity of Staphylococcus aureus to $\beta$-lactam antibiotics, the main group of antibiotics used to treat staphylococcal infections unless the isolate is a methicillin-resistant Staphylococcus aureus (MRSA). Although synergistic activity of component plants of Triphala with some antibiotics have been studied [14], the synergy between Triphala and gentamicin and oxacillin has not been studied previously to the best of our knowledge. The current study was therefore conducted with the objective of characterizing the antimicrobial activity of Triphala against multi-drug resistant (MDR) organisms and to evaluate synergistic activity with gentamicin and oxacillin against appropriate organisms.

\section{Methodology}

\section{Preparation of solid extract of Triphala}

Specimens of the three constituent plants of Triphala were identified and confirmed by the National Herbarium, Department of National Botanic Gardens, Peradeniya, Sri Lanka and deposited in the National Herbarium with the following tag numbers; Terminalia chebula - 522, Terminalia bellirica - 816 and Phyllanthus emblica -428 (letter No. 6/01/H/03, dated 2015.11.26 and 2016.01.07).

The dried fruits of T. chebula, T. bellirica and P. emblica bought from a Medicinal shop in Kandy, Sri Lanka were washed with sterile distilled water and crushed to remove the seeds. The pericarp of the three fruits were weighed separately ( $40 \mathrm{~g}$ each), mixed together, to prepare Triphala. An aqueous extract of Triphala was prepared by boiling the Triphala $(120 \mathrm{~g})$ in distilled water $(400 \mathrm{ml})$ to $1 / 8$ th the initial volume, meeting the conditions of traditional drug preparation. The aqueous extract was freeze-dried and the solid residue was stored in a deep freezer $\left(-20^{\circ} \mathrm{C}\right)$; the solid residue was used for preparing a dilution series of Triphala as described below.

\section{Microorganisms}

Synergistic activity was tested using 12 MDR pathogens: Serratia liquefaciens, Serratia marcescens, Serratia odorifera biogroup 1, Proteus spp., three isolates of Klebsiella pneumoniae, Enterobacter cloacae, two isolates of Pseudomonas aeruginosa, two isolates of Acinetobacter spp. and five isolates of Methicillin Resistant Staphylococcus aureus (MRSA) obtained from the Department of Microbiology, Faculty of Medicine, University of Peradeniya and Teaching Hospital, Peradeniya. The organisms were stored at $-80^{\circ} \mathrm{C}$ (Thermo Scientific freezer) until testing. Antibiotic susceptibility testing was performed for a selected group of drugs using the Clinical and Laboratory Standards Institute [15] recommendations, prior to testing for MIC.

\section{Preparation of the dilution series of Triphala and antibiotics}

The dilution series $5000-4.88 \mu \mathrm{g} / \mathrm{ml}$ of Triphala was prepared using a stock solution of Triphala $(10,000 \mu \mathrm{g} /$ $\mathrm{ml}$ ) by using double dilution method. Dilution series ranging from 5000 to $9.78 \mu \mathrm{g} / \mathrm{ml}$ was used to test synergistic activity of Triphala and gentamicin against the MDR Gram negatives and a dilution series ranging from 2500 to $4.88 \mu \mathrm{g} / \mathrm{ml}$ was used to test for synergy between Triphala and oxacillin against MRSA.

The dilution series of gentamicin used for synergy testing ranged from 64 to $2 \mu \mathrm{g} / \mathrm{ml}$. The dilution series of oxacillin used for synergy testing ranged from 32 to $0.5 \mu \mathrm{g} / \mathrm{ml}$.

\section{Synergistic activity}

Synergistic activity was tested using 2,3,5-triphenyltetrazolium chloride (TTC) assay, using sterile 96 well flat bottomed plates as described previously [16]. Results were read using a colour change.

\section{Calculation of mean fractional inhibitory concentration (FIC) index}

The value of the mean fractional inhibitory concentration (FIC) index as a predictor of synergy was calculated using the recorded MICs [17].

$$
\begin{aligned}
& \text { FIC index }=\text { FIC }_{(\operatorname{drug} \mathrm{A})}+\mathrm{FIC}_{(\text {drug B })} \\
& \mathrm{FIC}=\text { MIC of drug in combination/ } \\
& \text { MIC of drug tested individually }
\end{aligned}
$$

The interaction was defined as synergistic if the FIC index was $<1$, additive if the FIC index was 1 and antagonistic if the FIC index was $>1[16,18]$.

\section{Results}

All isolates tested were confirmed to be MDR organisms being resistant to three or more classes of antibiotics (Table 1).

\section{MIC values when tested alone and in combination}

When tested alone, the MIC values of gentamicin for the Gram negative isolates ranged from 8 to $>64 \mu \mathrm{g} / \mathrm{ml}$ (Table 2 and Additional file 1: Table S1). All enterobacteriaceae isolates had MICs within the resistant range to 


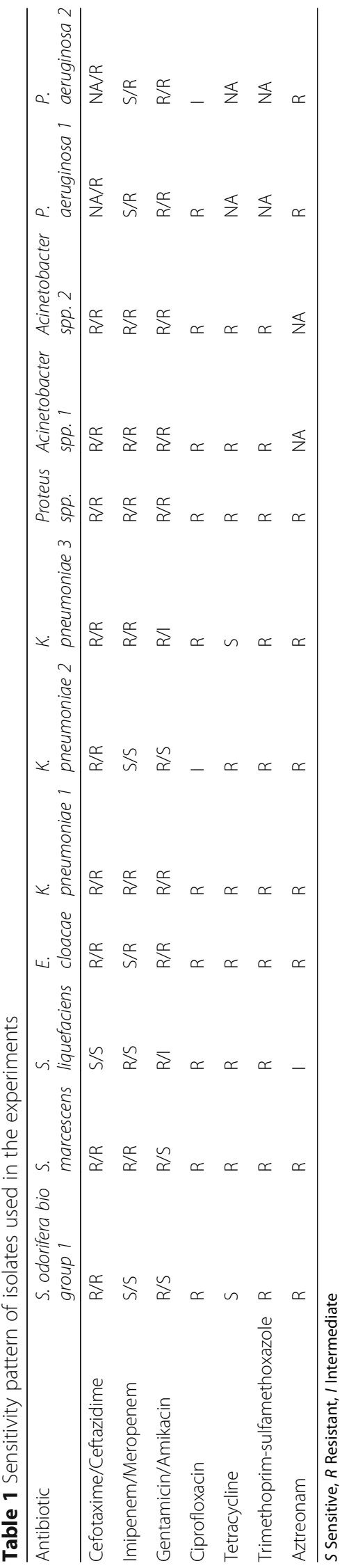


Table 2 Mean MICs of gentamicin and Triphala for MDR Gram negatives, when tested alone and in combination

\begin{tabular}{|c|c|c|c|c|c|}
\hline Isolate & $\begin{array}{l}\text { Mode MIC for gentamicin } \\
\text { alone } \mu \mathrm{g} / \mathrm{ml}\end{array}$ & Interpretation & $\begin{array}{l}\text { Mode MIC for gentamicin when } \\
\text { tested with Triphala } \mu \mathrm{g} / \mathrm{ml}\end{array}$ & Interpretation & $\begin{array}{l}\text { Mean concentration } \\
\text { of Triphala at which } \\
\text { synergy was shown } \mu \mathrm{g} / \mathrm{m}\end{array}$ \\
\hline S. liquefaciens & $>64$ & $\mathrm{R}$ & 1 & $S$ & 2500 \\
\hline $\begin{array}{l}\text { S. odorifera } \\
\text { biogroup } 1\end{array}$ & 64 & $\mathrm{R}$ & 8 & । & 625 \\
\hline S. marcescens & $>64$ & $\mathrm{R}$ & 32 & $\mathrm{R}$ & 625 \\
\hline Proteus spp. & $>64$ & $\mathrm{R}$ & 1 & S & 312 \\
\hline K. pneumonia 1 & 64 & $\mathrm{R}$ & 8 & I & 1250 \\
\hline K. pneumonia 2 & 32 & $\mathrm{R}$ & 1 & S & 1250 \\
\hline K. pneumonia 3 & 32 & $\mathrm{R}$ & 1 & S & 2500 \\
\hline E. cloacae & 64 & & 8 & I & 2500 \\
\hline $\begin{array}{l}\text { Acinetobacter } \\
\text { spp. } 1\end{array}$ & $>64$ & $\mathrm{R}$ & 2 & S & 625 \\
\hline $\begin{array}{l}\text { Acinetobacter } \\
\text { spp. } 2\end{array}$ & $>64$ & $\mathrm{R}$ & 8 & । & 156 \\
\hline P. aeruginosa 1 & 32 & $\mathrm{R}$ & 16 & $\mathrm{R}$ & 1250 \\
\hline P. aeruginosa 2 & 8 & S & 4 & S & 78 \\
\hline
\end{tabular}

$S$ Sensitive, $R$ Resistant, I Intermediate

gentamicin $(\geq 16 \mu \mathrm{g} / \mathrm{ml})$. The two acinetobacter spp. tested also had MICs that were considered resistant $(\geq 16 \mu \mathrm{g} / \mathrm{ml}$ ). One of the pseudomonads tested had a sensitive MIC value despite demonstrating a resistant zone diameter in the disc diffusion testing. The MIC values of gentamicin for these Gram negative isolates ranged from 1 to $32 \mu \mathrm{g} / \mathrm{L}$ on testing with Triphala. Six of the 11 isolates with MICs demonstrating resistance to gentamicin when tested alone had MICs in the sensitive range when tested with Triphala while four isolates had their MICs lowered to the intermediate sensitive level. One isolate remained resistant despite demonstrating a two-fold drop in the MIC.

The MIC values of oxacillin for the MRSA isolates ranged from 4 to $>16 \mu \mathrm{g} / \mathrm{ml}$ with all MICs being equal to or higher than the resistance cut-off level. The MIC level with the addition of Triphala ranged from 0.25 to $4 \mu \mathrm{g} / \mathrm{ml}$. Four out of the five isolates demonstrated a drop in the MIC to the sensitive range (Table 3 and Additional file 1: Table S2).
The FIC indices were calculated for gentamicin-Triphala and oxacillin-Triphala combinations (Table 4). Eleven of the twelve gentamicin-Triphala interactions and all oxacillin-Triphala interactions were synergistic while one gentamicin-Triphala interaction, for a Pseudomonas aeruginosa isolate was additive in nature. None of them were antagonistic.

\section{Discussion}

In the current study, we demonstrated that Triphala interacts in a synergistic manner with gentamicin against the selected MDR Gram negative bacilli and with oxacillin against MRSA. Aminoglycosides including gentamicin act by interfering with bacterial protein synthesis. Gentamicin has been used widely in combination with other $\beta$-lactam antibiotics [19]. Non-lethal damage by the $\beta$-lactam antibiotics to the cell wall of bacteria is considered to facilitate the entry of the aminoglycoside antibiotic to the bacterial cell, enhancing its killing ability [20]. Aminoglycoside resistance, including resistance to gentamicin occurs through enzymatic deactivation of the

Table 3 Mean MICs of oxacillin and Triphala for MRSA isolates, when tested alone and in combination

\begin{tabular}{|c|c|c|c|c|c|}
\hline Isolate & $\begin{array}{l}\text { Mode MIC for oxacillin } \\
\text { alone }(\mu \mathrm{g} / \mathrm{ml})\end{array}$ & Interpretation & $\begin{array}{l}\text { Mode MIC for oxacillin when } \\
\text { tested with Triphala }(\mu \mathrm{g} / \mathrm{ml})\end{array}$ & Interpretation & $\begin{array}{l}\text { Mean concentration of Triphala } \\
\text { at which synergy was shown }(\mu \mathrm{g} / \mathrm{ml})\end{array}$ \\
\hline MRSA 1 & $>16$ & $R$ & 1 & $S$ & 78 \\
\hline MRSA 2 & 4 & $\mathrm{R}$ & 0.25 & S & 78 \\
\hline MRSA 3 & $>16$ & $\mathrm{R}$ & 0.25 & S & 78 \\
\hline MRSA 4 & $>16$ & $\mathrm{R}$ & 4 & $R$ & 39 \\
\hline MRSA 5 & 16 & $\mathrm{R}$ & 2 & S & 78 \\
\hline
\end{tabular}

$S$ Sensitive, $R$ Resistant 
Table 4 FIC index of antibiotic (gentamicin/oxacillin) and Triphala for the MDR bacterial isolates

\begin{tabular}{|c|c|c|c|c|}
\hline Isolate & FIC of antibiotic & FIC of Triphala & FIC index & Interpretation \\
\hline \multicolumn{5}{|l|}{ Gentamicin and Triphala } \\
\hline S. liquefaciens & $<0.016$ & $<0.25$ & $<0.266$ & Synergistic \\
\hline S. odorifera biogroup 1 & 0.125 & 0.25 & 0.375 & Synergistic \\
\hline S. marcescens & $<0.5$ & 0.25 & $<0.75$ & Synergistic \\
\hline Proteus spp. & $<0.016$ & 0.25 & $<0.27$ & Synergistic \\
\hline K. pneumonia 1 & 0.125 & 0.25 & 0.375 & Synergistic \\
\hline K. pneumonia 2 & 0.031 & 0.25 & 0.281 & Synergistic \\
\hline K. pneumonia 3 & 0.031 & 0.5 & 0.531 & Synergistic \\
\hline E. cloacae & 0.125 & 0.5 & 0.625 & Synergistic \\
\hline Acinetobacter spp. 1 & $<0.031$ & 0.25 & $<0.281$ & Synergistic \\
\hline Acinetobacter spp. 2 & $<0.125$ & 0.061 & $<0.186$ & Synergistic \\
\hline P. aeruginosa 1 & 0.5 & 0.5 & 1 & Additive \\
\hline P. aeruginosa 2 & 0.5 & 0.13 & 0.63 & Synergistic \\
\hline \multicolumn{5}{|l|}{ Oxacillin and Triphala } \\
\hline MRSA 1 & $<0.06$ & 0.25 & $<0.31$ & Synergistic \\
\hline MRSA 2 & 0.06 & 0.5 & 0.56 & Synergistic \\
\hline MRSA 3 & $<0.016$ & 0.5 & $<0.516$ & Synergistic \\
\hline MRSA 4 & $<0.25$ & 0.25 & $<0.5$ & Synergistic \\
\hline MRSA 5 & 0.125 & 0.5 & 0.625 & Synergistic \\
\hline
\end{tabular}

drug, active efflux of the drug or cell wall changes leading to reduced uptake of the drug and decreased binding of the drug to the $16 \mathrm{~S}$ ribosome due to mutations or methylation [19]. Both ethanolic and aqueous extracts of Triphala contain phenolics, flavonoids and carotenoids [21]. Antibacterial activity of Triphala has been shown to correlate to its phenolic content [22]. Phenolic compounds are known to disrupt the cell membranes of bacteria [23]. Therefore, the mechanism of synergy between gentamicin and Triphala may be similar to that between gentamicin and $\beta$-lactams.

Oxacillin acts by interfering with cell wall synthesis. The main mechanism of resistance to all $\beta$-lactams in MRSA is the presence of PBP2a that has a lower affinity to this group of drugs [24]. Synergy between phenolic compounds and oxacillin against MRSA, similar to our findings, has been documented previously $[25,26]$.

The chemical structures of active phenolic compounds determine their antibacterial activity [23]. Therefore, it is important that the active phytochemicals of Triphala be identified and their structures elucidated in furthering this study.

While synergism or additive activity was noted across all antimicrobial-plant compounds tested in the study, not all gentamicin MIC drops resulted in achieving clinical sensitive breakpoints. Furthermore, no consistency has been observed in the reversion of gentamicin MIC to sensitive levels across the organisms tested. Presence of varying mechanisms of resistance among the test isolates may have contributed to this. As the mechanisms of resistance for the test isolates were not established, we are unable to further validate this claim.

While there was a drop in the MIC of Triphala against all organisms tested when used in combination with the antibiotics, the values remained relatively high (original MIC values not shown). However, the reported MIC values for Triphala and its constitutive plant products when tested alone has ranges similar to that obtained in our study [22, 23]. Similar levels have been reported for other plant products as well [27, 28].

Aminoglycoside use had increased in the recent past for the treatment of infections caused by MDR organisms as the rate of emergence of resistance to aminoglycosides has been low. However, the reason for discontinuation of the aminoglycoside in many instances is nephrotoxicity [29]. Interestingly, Triphala has renal protective effects both in animal studies [30] and limited clinical studies [31], presumably due to its antioxidant properties. In vitro and invivo studies of Triphala and gentamicin together to explore the possible benefits are warranted in future.

\section{Conclusion}

In conclusion, Triphala demonstrated synergistic activity with gentamicin against selected MDR Gram negative bacilli and with oxacillin against MRSA, warranting 
further studies to identify the possibility of using such combinations in clinical practice.

\section{Additional file}

Additional file 1: Table S1. Result of the triplicates - the MICS of gentamicin and Triphala for MDR Gram negatives, when tested alone and in combination. Table S2. Result of the triplicates -MICs of oxacillin and Triphala for MRSA isolates, when tested alone and in combination. (DOC $60 \mathrm{~kb}$ )

\section{Abbreviations}

AMR: Antimicrobial resistance; FIC: Fractional inhibitory concentration; MDR: Multi drug resistant; MIC: Minimum inhibitory concentration; MRSA: Methicillin Resistant Staphylococcus aureus; TTC: 2,3,5Triphenyltetrazolium chloride

\section{Authors' contributions}

AM: Conceptualization of the study, conducting the lab work, data analysis drafting and final approval of the paper, VT: Conceptualization of the study, data analysis drafting and final approval of the paper, RB: Conceptualization of the study, drafting and final approval of the paper, AE: Laboratory protocols, conducting laboratory word, drafting and final approval of the paper, VL: Laboratory protocols, drafting and finalizing the paper. All authors read and approved the final manuscript.

\section{Funding}

This study was funded through a National Research Council of Sri Lanka grant (NRC 11-122) awarded to VT.

\section{Availability of data and materials}

The datasets used and/or analysed during the current study are available from the corresponding author on reasonable request.

\section{Ethics approval and consent to participate}

Not applicable.

\section{Consent for publication}

Not applicable.

\section{Competing interests}

The authors declare that they have no competing interests.

\section{Author details}

${ }^{1}$ Department of Ayurveda, Central Province, Kundasale, Sri Lanka.

${ }^{2}$ Department of Microbiology, Faculty of Medicine, University of Peradeniya, Peradeniya, Sri Lanka. ${ }^{3}$ Department of Chemistry, Faculty of Science, University of Peradeniya, Peradeniya, Sri Lanka.

Received: 20 July 2017 Accepted: 25 July 2019

Published online: 02 August 2019

\section{References}

1. Mohan RC. Pathinen Siddharkal Arulich Seitha Pathrthaguna Cinthamani: Thamari library; 2006.

2. Ayurvedic Pharmacopoeia Committee. The Ayurvedic formulary of India, part II. New Delhi: The controller of publications civil lines, Delhi, on behalf of the Government of India, Ministry of Health and Family Welfare, Department of Indian Systems of Medicine and Homeopathy; 2002.

3. Murugesa Mudaliar KS. Siddha Materia Medica (Part I) (Medicinal Plants Division), Directorate of Indian Medicine \& Homeopathy, Chennai-106; 2013.

4. Baliga MS, Meera S, Mathai B, Rai MP, Pawar V, Palatty PL. Scientific validation of the ethnomedicinal properties of the Ayurvedic drug Triphala: a review. Chin J Integr Med. 2012;18(12):946-54. https://doi.org/10.1007/ s11655-012-1299-x Epub 2012 Dec 13. Review. PubMed PMID: 23239004

5. Kesharwani A, Polachira SK, Nair R, Agarwal A, Mishra NN, Gupta SK. Anti-HSV-2 activity of Terminalia chebula Retz extract and its constituents, chebulagic and chebulinic acids. BMC Complement Altern Med. 2017;17(1):110. https://doi. org/10.1186/s12906-017-1620-8 PubMed PMID: 28196487; PubMed Central PMCID: PMC5310005.

6. Hazra B, Sarkar R, Biswas S, Mandal N. Comparative study of the antioxidant and reactive oxygen species scavenging properties in the extracts of the fruits of Terminalia chebula, Terminalia belerica and Emblica officinalis. BMC Complement Altern Med. 2010;10:20. https://doi.org/10.1186/1472-6882-1 0-20 PubMed PMID: 20462461; PubMed Central PMCID: PMC2887379.

7. Srikumar R, Parthasarathy NJ, Shankar EM, Manikandan S, Vijayakumar R, Thangaraj R, Vijayananth K, Sheeladevi R, Rao UA. Evaluation of the growth inhibitory activities of Triphala against common bacterial isolates from HIV infected patients. Phytother Res. 2007;21(5):476-80 PubMed PMID: 17273983.

8. Sumathi P, Parvathi A. Antibacterial potential of the three medicinal fruits used in Triphala: an Ayurvedic formulation. J Med Plant Res. 2010;4(16): 1682-5. https://doi.org/10.5897/JMPR10.309.

9. Tambekar DH, Dahikar SB. Antibacterial activity of some Indian Ayurvedic preparations against enteric bacterial pathogens. J Adv Pharm Technol Res. 2011;2(1):24-9. https://doi.org/10.4103/2231-4040.79801 PubMed PMID: 22171288; PubMed Central PMCID: PMC3217688.

10. Dharmaratne MPJ, Manoraj A, Thevanesam V, Bandara BMR, Kumar NS, Ekanayake A. Antibacterial activity of aqueous extracts of Terminalia chebula fruit against some multidrug-resistant human pathogens. Int J Res Pharmaceut Biomed Sci. 2013;4:1333-7.

11. Prabhakar J, Senthilkumar M, Priya MS, Mahalakshmi K, Sehgal PK, Sukumaran VG. Evaluation of antimicrobial efficacy of herbal alternatives (Triphala and green tea polyphenols), MTAD, and 5\% sodium hypochlorite against Enterococcus faecalis biofilm formed on tooth substrate: an in vitro study. J Endod. 2010;36(1):83-6. https://doi.org/10.1016/j.joen.2009.09.040 PubMed PMID: 20003940.

12. Bajaj N, Tandon S. The effect of Triphala and chlorhexidine mouthwash on dental plaque, gingival inflammation, and microbial growth. Int J Ayurveda Res. 2011;2(1):29-36. https://doi.org/10.4103/0974-7788.83188 PubMed PMID: 21897640; PubMed Central PMCID: PMC3157106.

13. Kumar MS, Kirubanandan S, Sripriya R, Sehgal PK. Triphala incorporated collagen sponge--a smart biomaterial for infected dermal wound healing. J Surg Res. 2010;158(1):162-70. https://doi.org/10.1016/j.jss.2008.07.006 PubMed PMID: 19118845.

14. Phatthalung PN, Chusri S, Voravuthikunchai SP. Thai ethnomedicinal plants as resistant modifying agents for combating Acinetobacter baumannii infections. BMC Complement Altern Med. 2012;12:56. https://doi.org/10.11 86/1472-6882-12-56 PubMed PMID: 22536985; PubMed Central PMCID: PMC3416686.

15. Clinical and Laboratory Standards Institute (CLSI). Performance standards for antimicrobial susceptibility testing; twenty-fourth informational supplement. CLSI document M100-S24. Wayne. 2014;34(1).

16. Bonapace CR, Bosso JA, Friedrich LV, White RL. Comparison of methods of interpretation of checkerboard synergy testing. Diagn Microbiol Infect Dis. 2002;44(4):363-6 PubMed PMID: 12543542.

17. Hall MJ, Middleton RF, Westmacott D. The fractional inhibitory concentration (FIC) index as a measure of synergy. J Antimicrob Chemother 1983;11(5):427-33 PubMed PMID: 6874629.

18. Te Dorsthorst DT, Verweij PE, Meis JF, Punt NC, Mouton JW. Comparison of fractional inhibitory concentration index with response surface modeling for characterization of in vitro interaction of antifungals against itraconazolesusceptible and -resistant Aspergillus fumigatus isolates. Antimicrob Agents Chemother. 2002;46(3):702-7 PubMed PMID: 11850251; PubMed Central PMCID: PMC127491.

19. Bennett JE, Dolin R, Blaser MJ. Mandell, Douglas, and Bennett's principles and practice of infectious diseases. 8th ed. Philadelphia: Churchill Livingstone Elsevier; 2015.

20. Davis BD. Bactericidal synergism between beta-lactams and aminoglycosides: mechanism and possible therapeutic implications. Rev Infect Dis. 1982:4(2):237-45 Review. PubMed PMID: 7051225.

21. Amanullah S, Chandramoorthy HC, Kumar VA, Khatheeja S. Antimicrobia activity of Triphala against bacterial isolates from HIV infected patients. Jundishapur J Microbiol. 2011;4(1):S9-S17.

22. Bag A, Bhattacharyya SK, Pal NK. Antibacterial potential of hydroalcoholic extracts of triphala components against multidrug-resistant uropathogenic bacteria--a preliminary report. Indian J Exp Biol. 2013;51(9):709-14 PubMed PMID: 24377130

23. Gyawali R, Ibrahim SA. Natural products as antimicrobial agents. Food Control. 2014;46:412-29. https://doi.org/10.1016/j.foodcont.2014.05.047. 
24. Stapleton PD, Taylor PW. Methicillin resistance in Staphylococcus aureus: mechanisms and modulation. Sci Prog. 2002;85(Pt 1):57-72 Review. PubMed PMID: 11969119; PubMed Central PMCID: PMC2065735.

25. Basri DF, Sandra V. Synergistic interaction of methanol extract from Canarium odontophyllum Miq. Leaf in combination with oxacillin against methicillin-resistant Staphylococcus aureus (MRSA) ATCC 33591. Int J Microbiol. 2016;2016:5249534. https://doi.org/10.1155/2016/5249534 Epub 2016 Feb 23. PubMed PMID: 27006659; PubMed Central PMCID: PMC4781960.

26. Sanhueza L, Melo R, Montero R, Maisey K, Mendoza L, Wilkens M. Synergistic interactions between phenolic compounds identified in grape pomace extract with antibiotics of different classes against Staphylococcus aureus and Escherichia coli. PLoS One. 2017;12(2):e0172273. https://doi.org/10.1371/ journal.pone.0172273 eCollection 2017. PubMed PMID: 28235054; PubMed Central PMCID: PMC5325233.

27. Silva O, Serrano R. In: Méndez-Vilas A, editor. Terminalia genus as source of antimicrobial agents. The battle against microbial pathogens: basic science, technological advances and educational programs; 2015. p. 236-45.

28. Teka A, Rondevaldova J, Asfaw Z, Demissew S, Van Damme P. Kokoska L, Vanhove W. In vitro antimicrobial activity of plants used in traditional medicine in Gurage and Silti zones, south Central Ethiopia. BMC Complement Altern Med. 2015;15:286. https://doi.org/10.1186/s12 906-015-0822-1 PubMed PMID: 26283630; PubMed Central PMCID: PMC4539890.

29. Leibovici L, Vidal L, Paul M. Aminoglycoside drugs in clinical practice: an evidence-based approach. J Antimicrob Chemother. 2009;63(2):246-51. https://doi.org/10.1093/jac/dkn469 Epub 2008 Nov 19. Review. PubMed PMID: 19022778.

30. Baskaran UL, Martin SJ, Mahaboobkhan R, Prince SE. Protective role of Triphala, an Indian traditional herbal formulation, against the nephrotoxic effects of bromobenzene in Wistar albino rats. J Integr Med. 2015;13(2):115-21. https://doi.org/10.1016/S2095-4964(15)60165-0 PubMed PMID: 25797642

31. Akarshini AM, Aruna. Management of Madhumeha Janya Upadrava with special reference to diabetic nephropathy - a clinical study. Ayu. 2014;35(4): 378-83. https://doi.org/10.4103/0974-8520.158987 PubMed PMID: 26195899; PubMed Central PMCID: PMC4492021.

\section{Publisher's Note}

Springer Nature remains neutral with regard to jurisdictional claims in published maps and institutional affiliations.

Ready to submit your research? Choose BMC and benefit from:

- fast, convenient online submission

- thorough peer review by experienced researchers in your field

- rapid publication on acceptance

- support for research data, including large and complex data types

- gold Open Access which fosters wider collaboration and increased citations

- maximum visibility for your research: over $100 \mathrm{M}$ website views per year

At $\mathrm{BMC}$, research is always in progress.

Learn more biomedcentral.com/submissions 